\title{
Evaluation of Nutrient Content of Vermicompost Made from Different Substrates at Mechara Agricultural Research Center on Station, West Hararghe Zone, Oromia, Ethiopia
}

\author{
Tadele Geremu ${ }^{1, ~ *}$, Habtamu Hailu², Alemayhu Diriba ${ }^{2}$ \\ ${ }^{1}$ Oromia Agricultural Research Institute, Fitche Agricultural Research Center, Soil Fertility Improvement and Problematic Soil Research \\ Team, Fitche, Ethiopia \\ ${ }^{2}$ Oromia Agricultural Research Institute, Mechara Agricultural Research Center, Soil Fertility Improvement Research Team, Mechara, \\ Ethiopia
}

Email address:

bekgeremu@gmail.com (T. Geremu)

${ }^{*}$ Corresponding author

\section{To cite this article:}

Tadele Geremu, Habtamu Hailu, Alemayhu Diriba. Evaluation of Nutrient Content of Vermicompost Made from Different Substrates at Mechara Agricultural Research Center on Station, West Hararghe Zone, Oromia, Ethiopia. Ecology and Evolutionary Biology.

Vol. 5, No. 4, 2020, pp. 125-130. doi: 10.11648/j.eeb.20200504.12

Received: September 26, 2020; Accepted: October 13, 2020; Published: October 30, 2020

\begin{abstract}
The study was conducted at Mechara Agricultural Research Centre during 2016-2018 to evaluate nutrient content of vermicompost made from different substrates. The treatments were sorghum straw, maize straw, teff straw, haricot bean straw, grass straw and mixture of all straws. A red worm (Eisenia fetida) was selected to digest the substrates. The substrates was chopped and added to the worm bin volume calculated using spherical frustum formula $1 / 6 \pi \mathrm{h}\left(3 \mathrm{a}^{2}+3 \mathrm{~b}^{2}+\mathrm{h}^{2}\right.$ in a ration $2.5: 1$ ration of cattle manure to crop residue in weight basis. Water was sprayed to maintain optimum moisture for worms as it needed. The vermi composting process was started by releasing 100 worms in to the substrates. Matured composite vermicompost samples were prepared and collected for laboratory analysis. The laboratory result showed that, the $\mathrm{pH}$ and EC values of all type of vermicompost are found in suitable range for survival of earthworms and also for plant growth. Data with regards to \%OC, $\mathrm{C}: \mathrm{N}$ ratio and $\mathrm{CEC}$ of vermicompost made from all material is excellent and promise for improvement of soil properties. Relatively the highest (4.26\%) and lowest (3.04\%) TN content was recorded from vermicompost made from grasses and haricot bean substrates respectively. The highest value of available $\mathrm{P}$ and $\mathrm{K}$ was also registered from vermicompost prepared from all materials. Even if the values of recorded exchangeable $\mathrm{Ca}, \mathrm{Mg}, \mathrm{K}$ and extractable micro nutrients were different, the vermicompost obtained from all substrates were rich in exchangeable cations and micro nutrients. Therefore, the nutrient content of vermicompost prepared from all substrates showed the highest values for all macro and micro plant nutrients. Thus, the vermicompost made from all materials could correct the plant nutrient imbalance and could be used for vermicompost preparation based on the accessibility of materials. Also utilizing the vermicompost for crop production and enhancing soil fertility.
\end{abstract}

Keywords: Nutrient, Soil Fertility, Straw, Substrates, Vermicompost

\section{Introduction}

Applications of heavy doses of chemical fertilizers and pesticides have increased the social and environmental risks across the globe. It has also affected soil microbes and fertility as well as minimized the resistance and power of plant against insect-pest and other prevailing diseases [33]. The uses of these synthetic fertilizers have also adversely affected the human health and agricultural products [28]. Recently, the scientific community is trying to adopt the environmentally friendly, economically viable, safe and sustainable ways of soil fertilization to avoid the danger of chemical fertilizers by replacing the chemical fertilizers by organic fertilizers $[33,11,19,8]$.

Vermicomposting is an environmentally friendly process of bio-oxidation and stabilization of organic wastes which is 
prepared from organic materials such as paper residues, crop residue, water hyacinth, animal dungs, industrial wastes, municipal sewage sludges, Khat left over and eucalyptus twigs $[11-14,19,8]$. Those organic materials decomposed by waste eater earthworms (epigeic in nature) into a nutritive organic fertilizer i.e. vermicompost, rich in humus, macronutrients, micronutrients, beneficial soil microflora, actinomycetes, and plant growth regulators, and using them as an alternative to agrochemicals [2].

Earthworms are sometimes mentioned as farmer's friends, soil managers and nature's ploughmen. They consume organic matter; promote soil aeration, fragmentation and mixing of mineral particles [32]. Some species of earthworms have the capability of consuming different organic wastes including animal manure, green manure, industrial wastes, sewage sludge and crop residues [10]. Red worms Eisenia fetida is most widely used species in Ethiopia, because these species being epigeic display characteristics like high rates of processing of organic wastes, high reproductive rates and tolerant to wide range of environmental factors. During feeding of waste materials earthworms disintegrate and improve decomposition of the product through microbial activities and thus finally convert the unstable organic material into a stabilized form called vermicompost [32].

The decomposition rate of vermicompost is faster than conventional compost because in vermicompost the transformation of organic materials takes place through earthworm gut where the end materials contain high microbial activities, rich in nutrient contents, plant growth regulator, thus it proved that earthworms are able to convert garbage into 'gold' [7]. In addition, bulk density, water holding capacity, $\mathrm{pH}$, electrical conductivity, nitrogen, phosphorus, and potassium content are improved by vermicomposting compare to composting material [9, 30]. Furthermore, vermicompost decreases the amount of heavy metal incorporated to soil compare to compost [22]. It has been also stated that vermicompost may have more compounds used as a plant hormone which enhances plant growth and development compare to compost $[6,26]$.

According to many study conducted in Ethiopia, vermicompost have high nutrient content and good quality. [8] reported that, the vermicompost prepared from the combination of soya bean straw and cattle manure showed high nutrient value and good quality and thus popularized the technology for farmers. [11, 19] indicated that, vermicompost originated from khat left over and eucalyptus twigs has high nutrient contents and able to produce good quality of vermicompost. Besides increasing plant nutrients, vermicompost also improve growth, total dry matter and grains yield of different crops. Therefore, its effect has been tested by many researcher and scholars. The results showed significant difference on plant growth and yield if it is integrated with chemical fertilizers. Integrated use of vermicompost and NPS fertilizer gave higher maize yield in vertisol of Ambo [36]. Application of vermicompost and
NPS fertilizers gave higher Teff yields and highest marginal rate of return in North Western Zone of Tigray Region, Ethiopia. The highest marketable yield of Potato was recorded by the application of vermicompost and Chemical fertilizers [19]. Application of nitrogen and vermicompost significantly reduced infestation of Striga in sorghum, improved soil moisture and nutrient contents, and enhanced growth and yield of the crop [3]. Combined application of vermicompost and NPK fertilizers has also significantly increased nutrient uptake, yield and yield components of wheat [24]. Combined use of vermicompost and chemical P fertilizer with lime is economically optimum and could be recommended for reclaiming soil acidity and improve nutrients for maize as it enhanced grain yield and yield components of maize plant in strongly acidic soils of Western Highlands of Ethiopia [1].

West Hararghe zone produces huge amount of crop residues and cow dung since the farmers practiced mixed farming systems. Therefore huge amount of organic materials are available for vermicomposting as a substitute for chemical fertilizers and also used for integrated application of vermicompost and chemical fertilizers for the crop. Therefore, keeping in view the importance of vermicompost, the present study was designed with the aim to evaluate the nutrient content of vermicompost made from different substrate in West Hararghe Zone, Oromia Region, Ethiopa.

\section{Material and Methods}

\subsection{Description of the Study Area}

The study was conducted in Daro lebu District, at Mechara Agricultural Research Centre in 2017/2018. The district is located in West Hararghe Zone, Eastern Ethiopa at a distance of $434 \mathrm{~km}$ to the East of Addis Ababa and about $115 \mathrm{~km}$ from Chiro, capital town of the zone. It lies at longitude of $40^{\circ} 19.114^{\prime} 00^{\prime \prime} \mathrm{E}$ and latitude of $08^{\circ} 35.589$ ' $00^{\prime}$ 'N and at an altitude of $1750 \mathrm{~m}$ above sea level. The area is characterized by a bimodal rainfall pattern of distribution. The short rainy season usually starts in March and extends to May, while the main/long rainy season stretches from end of June to September. The ambient temperature of the district varies from 14 to $26^{\circ} \mathrm{C}$ with an average of $20^{\circ} \mathrm{C}$ (McARC Metrological Station, 2010-2018).

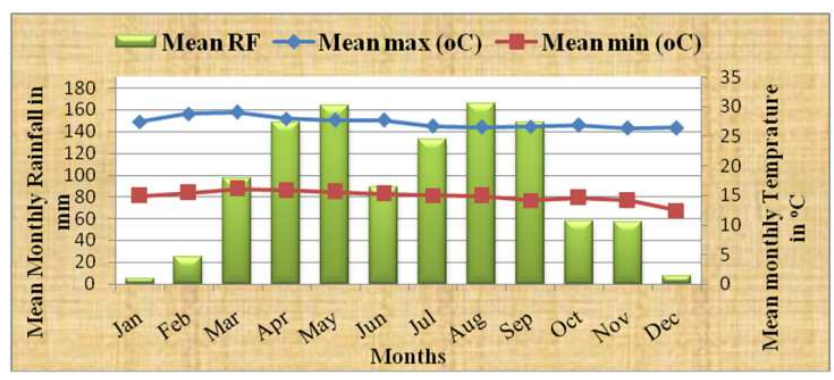

Figure 11. Mean monthly rainfall, maximum and minimum temperatures of the study area from 2010-2018 (Mechara Agricultural Research Center Meteorological station). 


\subsection{Establishment of Vermiculture}

Vermiculture was constructed for vermicompost production and multiplication of worms in Mechara Agricultural Research Center. The size of houses/vermiculture was $4 \times 5 \mathrm{~m}$ and the worm bin of shallow boxes were constructed in the house with the dimension of $0.4 \mathrm{~m}$ of depth, $0.5 \mathrm{~m}$ of width and $1 \mathrm{~m}$ of length from concrete cement. Corrugated iron sheet was used to cover the top of the house and the sides of the house were covered by mesh wire in order to protect sunlight and rain and to avoid the entrance of flying predators from a worm. In addition, ash was used to control small ants.

\subsection{Experimental Materials and Vermicompost Preparation}

Vermicompost was prepared from different substrate materials that were locally available crop residues: Maize, sorghum, haricot bean, grasses and the whole mixture of straws and grass as a bedding material. Cattle manure was added to all substrates in equal amount. The collected substrates were chopped and added to the worm bin for the purpose of earth worm multiplication. A red worm (Eisenia fetida) was used as a decomposer, which was collected from Haramaya University. However, for the treatment purpose, plastic bag were used to apply the treatments/substrates in the vermiculture.

After all substrates chopped, they was added to plastic bags and mixed with decomposed cattle manure in a ration of crop residue to cattle manure 2.5:1 on weight basis. Water was sprayed to maintain optimum moisture for worms as it needed. A total of $3 \mathrm{~kg}$ of substrates were filled the plastic bag which have a volume of $0.047 \mathrm{~m}^{3}$ based on the formula calculated as spherical frustum formula $1 / 6 \pi \mathrm{h}\left(3 \mathrm{a}^{2}+3 \mathrm{~b}^{2}+\mathrm{h}^{2}\right)$ [18].. The vermicomposting process was started by releasing 100 worms in to the substrates where the three most important environmental factors (temperature, adequate moisture and ventilation) were maintained [17]. Bottom face of plastic bag was drilled to avoid water logging.

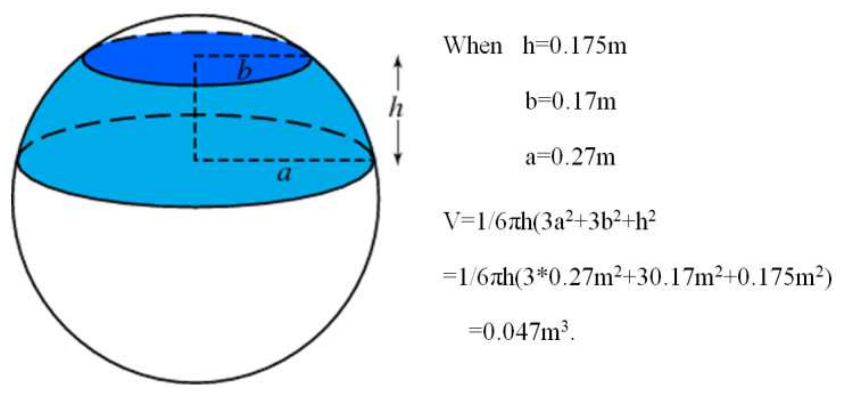

Figure 2. Spherical frustum formula.

The materials/substrates were transformed in to vermicompost after 3 months to give uniform humus in which no food scraps and residue materials are identifiable. The matured vermicompost was light and black or dark brown in color. The matured vermicompost was collected by manual harvesting which involved hand-sorting, or picking the worms directly from the vermicompost by hand. The vermicomposts were dried and their representative samples were taken and prepared for laboratory test. The laboratory analytical values are the averages of triplicate for interpretation of the results.

\subsection{Vermicompost Samples Analysis Methods}

The collected vermicompost samples were analyzed for the parameters stated in the table below.

Table 1. Different parameters analysed for vermicompost samples and analysis methods.

\begin{tabular}{lll}
\hline Parameter & unit & methods \\
\hline $\mathrm{pH}\left(\mathrm{H}_{2} \mathrm{O}\right)$ & - & Potentiometric water extract \\
$\mathrm{EC}$ & $\mathrm{mS} / \mathrm{cm}$ & Conductivity Cell Potentiometric \\
$\mathrm{P}_{\text {avail. }}$ & $\mathrm{mg} \mathrm{P}_{2} \mathrm{O}_{5} / \mathrm{kg}$ soil $)$ & Olsen \\
$\mathrm{K}_{\text {avail. }}$ & $\mathrm{mgK}_{2} \mathrm{O} / \mathrm{kg}$ soil & Ammonium Acetate \\
$\mathrm{OC}$ & $\%$ & Walklay Black \\
$\mathrm{TN}$ & $\%$ & Kjeldehal \\
Exchangeable $\mathrm{Ca}$ & $\mathrm{meq} / 100$ gm of soil & Ammonium Acetate \\
Exchangeable $\mathrm{Mg}$ & $\mathrm{meq} / 100$ gm of soil & Ammonium Acetate \\
Exchangeable $\mathrm{Na}$ & $\mathrm{meq} / 100$ gm of soil & Ammonium Acetate \\
Exchangeable $\mathrm{K}$ & $\mathrm{meq} / 100$ gm of soil & Ammonium Acetate \\
CEC & $\mathrm{meq} / 100$ gm of soil & Ammonium Acetate \\
Extractable $\mathrm{Fe}$ & $\mathrm{mg} / \mathrm{kg}$ soil & DTPA Extraction \\
Extractable $\mathrm{Zn}$ & $\mathrm{mg} / \mathrm{kg}$ soil & DTPA Extraction \\
Extractable $\mathrm{Cu}$ & $\mathrm{mg} / \mathrm{kg}$ soil & DTPA Extraction \\
Extractable $\mathrm{Mn}$ & $\mathrm{mg} / \mathrm{kg}$ soil & DTPA Extraction \\
\hline
\end{tabular}

\section{Data Analysis}

The experiment was a laboratory analytical procedure on the different materials where values recorded are means of triplicate values recorded and interpreted following previous standards.

\section{Result and Discussion}

\subsection{Chemical Properties of Vermicompost}

\subsection{1. $\mathrm{pH}\left(\mathrm{H}_{2} \mathrm{O}\right)$ and Electrical Conductivity $(\mathrm{EC})$}

According to the laboratory analysis result, the $\mathrm{pH}$ value of vermicompost was ranged from 7.51 to 8.43 (Table 2). Relatively the lowest and the highest $\mathrm{pH}$ value were recorded from the vermicompost prepared from the grass and sorghum straw respectively. A $\mathrm{pH}$ greater than 8.5 is harmful to microorganism [31]. Thus, the $\mathrm{pH}$ values of all type of vermicompost are found in suitable range for survival of earthworms and also for plant growth. Similarly [20] obtained similar results in which the $\mathrm{pH}$ status of vermicompost was ranged from 6.8-8.41. [8] also reported that, the $\mathrm{pH}$ values of vermicompost are more suitable for plant growth as compared to conventional compost.

The laboratory analysis result of electrical conductivity of vermicompost was ranged from 3.29 to $5.27 \mathrm{mS} \mathrm{cm}^{-1}$ (Table 1). The highest and the lowest mean value of EC was recorded from grass and sorghum straw respectively. Salinity which has the value of EC greater than $8 \mathrm{mS} \mathrm{cm}^{-1}$ is harmful to microorganism [31]. Therefore, the values of EC of vermicompost made from all materials are suitable for 
survival of earthworm and applicable for crop production.

\subsubsection{Organic Carbon, $C: N$ Ratio and Cation Exchange Capacity (CEC)}

The analysed result showed that, relatively the highest mean value of organic carbon $(34.66 \%)$ was recorded under digested grass and the lowest $(21.26 \%)$ mean values of organic carbon was registered from the vermicompost prepared from haricot bean straw (Table 2). In general, the status of organic carbon in all types vermicompost is high when compared with its availability in garden soil. This finding is in conformity with the study of $[25,11,19,8]$ whose found that the worm castings (vermicompost) contain higher percentage of organic carbon as compared to conventional compost and garden soil. Low $\mathrm{C}$ : $\mathrm{N}$ ratio was registered from all types of vermicompost. Low $\mathrm{C}: \mathrm{N}$ ratio indicates higher rate of mineralization [5] and thus the vermicompost prepared from all substrates contains high percentage of total nitrogen. Therefore lower $\mathrm{C}$ : $\mathrm{N}$ ratio was recorded due to higher mineralization of nitrogen. In line with this result, several studies confirmed that the lowest $\mathrm{C}$ : $\mathrm{N}$ ratio was recorded from vermicompost $[23,21,34,13,19$, 8]. CEC of vermicompost made from all substrates was very high status which was ranged from 57.39 to $68.7 \mathrm{cmol}+\mathrm{kg}^{-1}$. This result confirmed the study conducted by [20] who found that $57.8 \mathrm{cmol}+\mathrm{kg}^{-1}$ of CEC in vermicompost.

Table 2. Chemical properties of vermicompost prepared from different materials.

\begin{tabular}{|c|c|c|c|c|c|c|}
\hline \multirow{2}{*}{ Parameters } & \multicolumn{6}{|c|}{ digested substrates } \\
\hline & Haricot bean & Grass & Mixed straw & Teff & Maize & Sorghum \\
\hline $\mathrm{pH}-\mathrm{H}_{2} \mathrm{O}(1: 2.5)$ & 8.41 & 7.51 & 8.09 & 8.15 & 8.39 & 8.43 \\
\hline $\mathrm{EC}(\mathrm{mS} / \mathrm{cm})(1: 2.5)$ & 4.06 & 5.27 & 3.69 & 4.21 & 4.51 & 3.29 \\
\hline CEC (meq/100 gm) & 57.39 & 58.26 & 63.04 & 68.70 & 66.09 & 63.04 \\
\hline Organic Carbon (OC) $(\%)$ & 21.26 & 34.66 & 27.08 & 27.00 & 28.21 & 23.35 \\
\hline C: N Ratio & 7.00 & 8.14 & 7.27 & 7.16 & 9.13 & 7.39 \\
\hline
\end{tabular}

The recorded values are means of triplicates.

\subsection{Nutrient Contents of Vermicompost}

\subsubsection{Total Nitrogen, Available Phosphorus and Potassium (NPK)}

Data with regards to nutrient content of vermicompost, relatively the highest $(4.26 \%)$ and lowest $(3.04 \%)$ total nitrogen content was recorded from vermicompost made from grasses and haricot bean substrates respectively (Table 3). Similarly, [21] reported that $3.50 \%$ of total nitrogen was recorded from vermicomost. [8] also reported that, the vermicompost obtained from the combination of Maize Stover, Niger seed residue and sheep manure as well as the compost from the combination of soybean residue, Niger seed straw and sheep Manure had a higher value of total nitrogen content. The analyzed result also showed that, relatively the lowest $(775.39 \mathrm{mg} / \mathrm{kg})$ and the highest $(1277.62 \mathrm{mg} / \mathrm{kg})$ available phosphorous was recorded from the vermicompost obtained from haricot bean straw and grasses respectively (Table 3). The enhanced $\mathrm{P}$ level in vermicompost suggests phosphorous mineralization during the process. The worms during vermicomposting converted the insoluble $\mathrm{P}$ into soluble forms with the help of P-solubilizing microorganisms through phosphatases present in the gut, making it more available to plants $[27,16]$. The study is in conformity with the result of Nagavallemma et al. (2004) who found that, the worm casting contains the highest available phosphorus contents with the values ranged from 1900 to $10,200 \mathrm{mg} / \mathrm{kg}$. The highest
$(7327.7 \mathrm{mg} / \mathrm{kg})$ and the lowest $(3740.40 \mathrm{mg} / \mathrm{kg})$ available potassium were recorded from the vermicompost prepared from teff and sorghum straw respectively (Table 3 ). The study is in line with the result of [25] who reported that, the highest $(1500$ to $7300 \mathrm{mg} / \mathrm{kg}$ ) available potassium was registered from vermicompost.

\subsubsection{Exchangeable Calcium, Magnesium and Potassium}

The exchange complex of the vermicompost is dominantly occupied by exchangeable calcium than other basic cations in proportion. The analyzed result showed that highest $(35.20$ meq/100 gm) and lowest $(26.80 \mathrm{meq} / 100 \mathrm{gm})$ exchangeable $\mathrm{Ca}^{2+}$ was recorded from vermicompost made from teff and haricot bean straw respectively while, the highest $(13.20 \mathrm{meq} / 100 \mathrm{gm})$ and lowest (10meq/100 gm) exchangeable magnesium was registered from vermicompost obtained from haricot bean and mixed straw substrates respectively. The highest (13.20meq/100gm) exchangeable potassium was recorded from vermicompost obtained from haricot bean straw and the lowest $(10 \mathrm{meq} / 100 \mathrm{gm})$ was obtained from mixed straw substrates (Table 3 ). In general, the vermicompost obtained from all substrates were rich in exchangeable cations. The result is in agreement with the findings of [4] reported that the exchangeable bases $\left(\mathrm{Ca}^{2+}\right.$, $\mathrm{Ma}^{2+}, \mathrm{K}^{+}$) were significantly increased in vermicompost as compared to pit compost.

Table 3. Macro and micro nutrient content of vermicompost prepared from different materials.

\begin{tabular}{|c|c|c|c|c|c|c|}
\hline \multirow{2}{*}{ Parameters } & \multicolumn{6}{|c|}{ digested substrates } \\
\hline & Haricot bean & Grass & Mixed straw & Teff & Maize & Sorghum \\
\hline Total Nitrogen (TN) (\%) & 3.04 & 4.26 & 3.73 & 3.77 & 3.09 & 3.16 \\
\hline Available P (AV. p) $\left(\mathrm{mg} \mathrm{P}_{2} \mathrm{O}_{5} / \mathrm{kg}\right)$ & 775.39 & 1277.62 & 829.91 & 1023.80 & 987.38 & 905.96 \\
\hline Available K (Av. K) $\left(\mathrm{mgK}_{2} \mathrm{O} / \mathrm{kg}\right)$ & 6963.6 & 4987.0 & 4571.5 & 7327.7 & 4545.47 & 3740.40 \\
\hline Exch. K (meq/100 gm) & 11.59 & 10.00 & 20.72 & 20.92 & 19.90 & 18.97 \\
\hline
\end{tabular}




\begin{tabular}{|c|c|c|c|c|c|c|}
\hline \multirow{2}{*}{ Parameters } & \multicolumn{6}{|c|}{ digested substrates } \\
\hline & Haricot bean & Grass & Mixed straw & Teff & Maize & Sorghum \\
\hline Exch. Ca (meq/100 gm) & 26.80 & 31.20 & 32.00 & 35.20 & 34.00 & 34.00 \\
\hline Exch. $\mathrm{Mg}(\mathrm{meq} / 100 \mathrm{gm})$ & 13.20 & 12.80 & 10.00 & 12.00 & 12.00 & 12.00 \\
\hline $\mathrm{Fe}(\mathrm{mg} / \mathrm{kg})$ & 29.56 & 29.05 & 38.23 & 54.24 & 46.01 & 46.02 \\
\hline $\mathrm{Mn}(\mathrm{mg} / \mathrm{kg})$ & 354.35 & 101.83 & 120.87 & 117.66 & 105.14 & 112.03 \\
\hline $\mathrm{Cu}(\mathrm{mg} / \mathrm{kg})$ & 4.24 & 1.30 & 2.67 & 0.90 & 4.20 & 6.67 \\
\hline $\mathrm{Zn}(\mathrm{mg} / \mathrm{kg}$ & 32.32 & 35.81 & 41.33 & 45.67 & 41.05 & 58.72 \\
\hline
\end{tabular}

The recorded values are means of triplicates.

\subsubsection{Extractable Iron, Manganese, Copper and Zinc}

The analyzed result revealed that the highest $\left(54.24 \mathrm{mg} \mathrm{kg}^{-1}\right)$ values of DTPA extractable iron was recorded from vermicompost made from teff straw and lowest $\left(29.05 \mathrm{mg} \mathrm{kg}^{-1}\right)$ value were registered from grass straw substrates. The highest (354.35 mg kg $\left.\mathrm{g}^{-1}\right)$ and the lowest $\left(101.83 \mathrm{mg} \mathrm{kg}^{-1}\right)$ extractable manganese were recorded from vermicompost prepared from haricot bean and grass straw substrates respectively. The highest (58.72 mg kg-1) Zinc content among treatment was vermicompost made from sorghum straw while the least (32.32 $\mathrm{mg} \mathrm{kg}^{-1}$ ) was recorded from haricot bean straw substrates. The highest $\left(6.67 \mathrm{mg} \mathrm{kg}^{-1}\right)$ and the lowest $(0.9 \mathrm{mg}$ $\mathrm{kg}^{-1}$ ) Copper content was recorded from vermicompost made from sorghum and teff straw substrates respectively (Table 3). Similarly, [15] was reported that, very high iron contents were recorded from vermicompost. [25, 29, 15, 21] indicated that $\mathrm{Mn}$ content of vermicompost was very high. Also, the result is in agreement with the findings of [15, 29], who found that very high $\mathrm{Zn}$ contents were recorded from vermicompost.

\section{Conclusion and Recommendation}

Vermicompost is nutritionally rich natural organic fertilizer, which releases nutrients in the soil and improves quality of the plants with renewed of physical and biological properties of soil. Though, vermicompost prepared from locally available materials such as haricot bean, grass, teff, maize and sorghum straw and mixture of all straws were analyzed for their nutrient evaluation. According to the result of this study, the nutrient content of vermicompost prepared from all substrates showed the highest values for all macro and micro plant nutrients. Thus, the vermicompost made from all materials could correct the plant nutrient imbalance if applied to the nutrient deficient soil and could be used for vermicompost preparation based on the accessibility of materials. In generally, there is a need for further studies on the rate of application of vermicompost and their effect on crop yields and soil physic chemical properties under field condition.

\section{Acknowledgements}

We would like to express our heartfelt and deep gratitude to staff members of soil fertility improvement Research case team of Mechara Agricultural Research Center for their active participation in conducting this experiment. On the other hand, we would like to thanks Haramaya University for providing the worms to launch the study. Also we would like to express our gratitude to Oromia Agricultural Research Institute for financing the project.

\section{References}

[1] Abdissa Bekele, Kibebew Kibret, Bobe Bedadi, Markku YliHalla, Tesfaye Balemi. 2018. Effects of Lime, Vermicompost, and Chemical P Fertilizer on Selected Properties of Acid Soils of Ebantu District, Western Highlands of Ethiopia. Applied and Environmental Soil Science, https://doi.org/10.1155/2018/8178305.

[2] Adhikary S. 2012. Vermicompost, the story of organic gold: A review, Agricultural Sciences, 3 (7), 905-917.

[3] Alemayehu Biri, Sheleme Kaba, Fikadu Taddesse, Nigussie Dechassa, Sharma JJ, Asrat Zewidi and Arvind Chavhan. 2016. Effect of Vermicompost and Nitrogen Application on Striga Incidence, Growth, and Yield of Sorghum [Sorghum bicolor (L.) Monech] in Fedis, eastern Ethiopia. International Journal of Life Sciences, 4 (3): 349-360.

[4] Amir Khan and Fouzia Ishaq, 2011. Chemical nutrient analysis of different composts (VermicompostandPitcompost) and their effect on the growth of a vegetative crop Pisumsativum. Asian Journal of Plant Science and Research, 1 (1): 116-130.

[5] Brady, N. and R. Weil. 2002. The Nature and Properties of Soils, 13th Edition. Prentice Hall. Upper Saddle River, New Jersey. 960 p.

[6] Coulibaly S. S and Zoro Bi. I. A. 2010. Influence of animal wastes on growth and reproduction of the African earthworm species Eudriluseugeniae (Oligochaeta). European Journal of Soil Biology, 46: 225-229.

[7] Crescent T. 2003. Vermicomposting. Development Alternatives (DA) Sustainable Livelihoods, Retrieved from: (http:// www.dainet.org/livelihoods/default.htm).

[8] Derib Kifle, Gemechu Shumi and Abera Degefa. 2017. Characterization of Vermicompost for Major Plant Nutrient Contents and Manuring Value. Journal of Science and Sustainable Development, 5 (2), 97-108.

[9] Doan TT, Henry-des-Tureaux T, Rumpe C, Janeau JL, Jouquet P. 2015. Impact of compost, vermicompost and biochar on soil fertility, maize yield and soil erosion in Northern Vietnam: a three year mesocosm experiment. Science Total Environment, 514: 147-154.

[10] Edwards CA. 1998. The use of earthworms in the breakdown and management of organic wastes. InC. A. Edwards (ed.) Earthworm Ecology, CRC Press, Boca Raton, FL, 327-354. 
[11] Eyasu Mekonnen and Anteneh Argaw, 2015. Bioconversion of Wastes (Khat Leaf Leftovers and Eucalyptus Twigs) into Vermicompost and Assessing Its Impact on Potato Yield. Journal of Agronomy, 14 (1): 37-42.

[12] Gajalakshmi S., Abbasi S. A. 2004. Vermiconversion of paper waste by earthworm born and grown in the waste-fed reactors compared to the pioneers raised to adulthood on cow dung feed, Bioresource Technololgy, (94) 53-56.

[13] Garg P., Gupta A. and Satya S. 2006. Vermicomposting of different types of waste using Eisenia foetida: a comparative study, Bioresource Technololgy, 97: 391-395.

[14] Garg V. K. and Yadav A. 2005. Growth and reproduction of Eisenia foetida in various animal wastes during vermicomposting. Applied Ecology and Environmental Research, 3 (2005) 51-59.

[15] George, C Dickerson, W. 1994. Chemical characteristics of garden compost and vermicompost. Guide H - 164.

[16] Ghosh, M, Chattopadhyay G. N. and K. Baral. 1999. Transformation of phosphorus during vermicomposting. Bioresource Technology, 69: 149-154.

[17] Glenn, M. 2009. Manual of On-Farm Vermicomposting and Vermiculture, Organic Agriculture Centre of Canada.

[18] Harris, J. W. and Stocker, H. "Spherical Zone (Spherical Layer).1998. Handbook of Mathematics and Computational Science. New York: Springer-Verlag, pp. 107-108.

[19] Hiranmai, Y. R. and Anteneh Argaw, 2016. Manurial value of khat waste vermicompost from Awday, Harar town, Ethiopia. International Journal of Recycling Organic Waste Agriculture, 5: $105-111$

[20] Jouquet E. P, Bloquel E, Thu D. T, Ricoy M, Orange D, Rumpel $\mathrm{C}$ and Tran D. T. 2013. Do Compost and Vermicompost Improve Macronutrient Retention and Plant Growth in Degraded Tropical Soils? Compost Science and Utilization, 19: 1, 15-24.

[21] Kalantari S, Hatami S, Ardalan M, Alikhani H. and Shorafa M. 2009. The effect of compost and vermicompost of yard leaf manure on growth of corn. African Journal of Agricultural Research, 5 (11), 1317-1323.

[22] Lim SL, Lee LH, Wu TY. 2016. Sustainability of using composting and vermicomposting technologies for organic solid waste biotransformation: recent overview, greenhouse gases emissions and economic analysis. Journal of Clean Production, 111: 262-278.

[23] Mirian R. Alves, Maria D. Landgraf and Maria O. O. Rezende. 2006. Sorption and Desorption of the Herbicide Alachlor on Humic Acid Fractions From Two Vermicomposts. Journal of Environmental Science and Health, 36 (6), 797-808.

[24] Molla Hadis, Gashaw Meteke, and Wassie Haile. 2018. Response of bread wheat to integrated application of vermicompost and NPK fertilizers. African Journal of Agricultural Research, 13 (1): 14-20.
[25] Nagavallemma K. P., Wani S. P, Stephane L, Padmaja V. V, Vineela C, Babu R. M and Sahrawat K. L. 2004. Vermicomposting: Recycling wastes into valuable organic fertilizer. Global Theme on Agrecosystems Report no. 8. Patancheru 502 324, Andhra Pradesh, India: International Crops Research Institute for the Semi-Arid Tropics. 20p.

[26] Najar IA, Khan AB, Hai A. 2015. Effect of macrophyte vermicompost on growth and productivity of brinjal (Solanummelongena) under field conditions. International Journal of Recycling Organic Waste Agriculture, 4: 73-83.

[27] Padmavathiamma, P. K., Li, L. Y., and Kumari, U. R. 2008. An experimental study of vermi-biowaste composting for agricultural soil improvement. Bioresource Technology, 99: $1672-1681$

[28] Rai N, Ashiya P, Rathore DS. 2014. Comparative Study of the Effect of Chemical Fertilizers and Organic Fertilizers on Eisenia foetida. International Journal of Innovation and research in Science, Engineering and Technology, 2 (5): 12991-12998.

[29] Rajiv K. Sinha, Sunita Agarwal, Krunal Chauhan, Vinod Chandran and Brijal Kiranbhai Soni. 2010. Vermiculture Technology: Reviving the Dreams of Sir Charles Darwin for Scientific Use of Earthworms in Sustainable Development Programs. Technology and Investment, 1: 155-172.

[30] Rakkani VM, Vincent S, Kumar, AS, Baskar K. 2018. Organic waste management by earthworm. Journal of Civil Engineering and Environmental Science, 3 (1): 13-17.

[31] Santamaria R. S, Ferrera C. R, Almaraz S. J. J, Galvis S. A, Barois B. I. 2001. Dynamics and relationships among microorganisms, C-organic and N-total during composting and vermicomposting. Agrociencia-Montecillo, 5 (4), 377-384.

[32] Saranraj P, Stella D. 2012. Vermicomposting and its importance in improvement of soil nutrients and agricultural crops. Novus Natural Science Research, 1 (1): 14-23.

[33] Sinha RK, Agarwal S, Chauhan K, Valani D. 2010. The wonders of earthworms and its vermicompost in farm production: Charles Darwin's 'friends of farmers', with potential to replace destructive chemical fertilizers from agriculture. Agricultural Science, 1 (2): 76-94.

[34] Suthar S. 2007. Production of vermifertilizer from guar gumindustrial wastes by using composting earthworms Perionyxsansbaricus (Perrier). Environmentalist, 27: 329335.

[35] Suthar S. 2009. Vermistabilization of municipal sewage sludge amended with sugarcane trash using epigeic Eisenia fetida (Oligochaeta). Journal of Hazardous Materials, 163: 199206.

[36] Tolera Abera, Tolcha Tufa, Buzayehu Tola and Haji Kumbi. 2019. Effects of Vermicompost and NPS Fertilizer rate on Yield and Yield Components of Highland Maize in Vertisol Ambo. Ethiopian Journal of Applied Science and Technology, 10 (1): 1-15. 